\title{
IMPACT OF SOIL RECONSTRUCTION METHOD ON NITRATE ACCUMULATION IN FORAGES GROWN FOR LIVESTOCK FEED ${ }^{1}$
}

\author{
C.D. Teutsch, W.L. Daniels, Z.W. Orndorff, M.M. Alley, K.R. Meredith, and W.M. Tilson ${ }^{2}$
}

\begin{abstract}
Past research has shown that the use of biosolids in the reclamation of drastically disturbed lands has increased forage yield and nutritive value with no detrimental effects on soils, vegetation, or water quality. One potential concern when using high rates of biosolids in reclamation programs is the accumulation of concentrations of nitrate in the forage tissue that could be dangerous or even toxic to ruminant livestock $(>0.5 \%)$. Past reclamation research in which biosolids have been used has not assessed these levels. The objective of this research was to determine the impact of soil reconstruction method on the concentrations of nitrate in forage tissue. This research was conducted at a mineral sands mine located in Dinwiddie County, VA. Soil reconstruction treatments were 1) Control: rip, lime, $\mathrm{P}$, and routine fertilization per crop management protocols, 2) Biosolids: rip, lime stabilized biosolids at 78 dry $\mathrm{Mg}$ per hectare, and routine fertilization per crop management protocols, and 3) Topsoil: rip, lime, P to subsoil, $15.25 \mathrm{~cm}$ of topsoil return, and routine fertilization per crop management protocols. The levels of biosolids used in this experiment resulted in the accumulation of high levels of nitrate in the forage tissue. One year after the soil reconstruction treatments were imposed and the plots were seeded to a grasslegume mixture, levels of nitrate in forages treated with biosolids were $2.5 \%$ $\left(\mathrm{NO}_{3}{ }^{-}\right)$. This is in the toxic range for ruminant livestock and these forages should not be fed. Initial results indicate that when biosolids are used in a reclamation program, forage must be carefully monitored for accumulation of nitrates in order to avoid potential livestock fatalities.
\end{abstract}

Additional Key Words: biosolids, nitrates, reclamation, forages

${ }^{1}$ Paper was presented at the 2008 National Meeting of the American Society of Mining and Reclamation, Richmond, VA, New Opportunities to Apply Our Science June 14-19, 2008. R.I. Barnhisel (Ed.) Published by ASMR, 3134 Montavesta Rd., Lexington, KY 40502

${ }^{2}$ C.D. Teutsch, Associate Professor, Southern Piedmont AREC, Blackstone, VA 23824 email: cteutsch@vt.edu, W. L. Daniels, Professor, Z. W. Orndorff, Senior Research Associate, M.M. Alley, Professor, K.R. Meredith, Graduate Research Assistant, Crop and Soil Environmental Sciences, VPI \& SU, Blacksburg, VA 24060, and W.M. Tilson, Research Associate, Southern Piedmont AREC, Blackstone, VA 23824.

Proceedings America Society of Mining and Reclamation, 2008 pp 1283-1294

DOI: $10.21000 / J A S M R 08011283$

http://dx.doi.org/10.21000/JASMR08011283 


\section{Introduction}

Significant areas of prime farmland in the upper Coastal Plain of Virginia have been disturbed by heavy mineral sands (Ti/Zr-bearing ilmenite, rutile, zircon) mining over the past 10 years. The new mine soils consist of variably mixed and segregated tailings and slimes which have been dewatered and graded. These soils exhibit physical and chemical properties that limit agricultural use due to the inherent infertility of the processed subsoils, the abrupt layering of slimes and tails that often occurs during re-deposition, and heavy compaction from grading. In the fall of 2004 the Carraway-Winn Reclamation Research Farm was developed at Iluka Resources Inc. to enable comparison of different soil reconstruction strategies for the return of mined lands to agricultural production.

Past research has demonstrated that amending drastically disturbed soils with organic materials improves overall reclamation success. The most common organic amendment used in mined land reclamation is biosolids. The application of biosolids has been shown to increase soil organic matter, cation exchange capacity, soil nutrient levels, water holding capacity, and soil aggregate stability (Haering et al., 2000). In addition to the positive impact of biosolids on chemical and physical soil characteristics, they have also been shown to increase forage yields, improve nutritive value, and enhance persistence of newly established stands when compared to using conventional fertilizer.

Health and environmental issues associated with biosolids use in reclamation programs are reviewed by Haering et al. (2000). Public concerns generally fall into three categories, pathogen transmission, nitrate contamination of ground and surface water, and heavy metal accumulation. Properly treated biosolids are essentially pathogen free and pose little or no risk to public health. In reclamation programs biosolids are applied at higher rates (25 to $100 \mathrm{Mg} \mathrm{ha}^{-1}$ which can in some cases result in the leaching of nitrates into ground water. However, since this is a one time application long-term effects on groundwater are limited. Improved pretreatment of industrial wastewaters has greatly reduced the amount of trace metals in municipal biosolids. In most cases trace metals form stable complexes in the soil and are not leached into groundwater (Page and Chang, 1994). In most cases, plants grown on biosolids amended mine soils have trace metal concentrations considered safe for plants and animals (Haering et al., 2000). 
Another area of concern when using high levels of biosolids in mined land reclamation programs that has received considerably less attention is nitrate accumulation in the forage tissue and its associated impact on livestock. Accumulation of nitrate in forage plants can pose serious health problems for ruminant livestock (Murphy and Smith, 1967). Estimates of the nitrate concentration in forage required to cause acute nitrate toxicity varies due to a number of factors, including rate and amount ingested, forage type, energy level of the diet, adaptation to a high nitrate ration, general health and condition of the animal, species of animal, and pregnancy (Wright and Davison, 1964). The maximum nitrate concentrations in forage tissue considered safe for ruminant livestock varies by author and study and ranges from 2,500 to 10,000 ppm nitrate (Baker and Tucker, 1971; Cheeke, 1998; Crawford et al., 1966; Emerick, 1974; Gilbert et al., 1971; Wright and Davison, 1964). Ball and coworkers (2007) have compiled a widely used scale for rating the potential toxicity of nitrate in forage for ruminant livestock (Table 1). This scale identifies forages that have less than 5000 ppm nitrate as being generally safe when fed with a balanced ration.

Table 1. Nitrate levels in forages for ruminant livestock.

\begin{tabular}{|c|c|c|c|}
\hline \multicolumn{2}{|c|}{ Nitrate Concentration } & \multirow[t]{2}{*}{ Forage Status } & \multirow[t]{2}{*}{ Comments } \\
\hline ----\%---- & ---ppm--- & & \\
\hline $0-0.25$ & $0-2,500$ & SAFE & Considered safe. \\
\hline $0.25-0.5$ & $2,500-5,000$ & CAUTION & $\begin{array}{l}\text { Generally safe when fed with balanced ration. } \\
\text { Can be a problem for pregnant and young } \\
\text { animals. Limit to } 1 / 2 \text { of ration. Do not feed with } \\
\text { non-protein N. Check water for nitrates. }\end{array}$ \\
\hline $0.5-1.5$ & $5,000-15,000$ & DANGER & $\begin{array}{l}\text { Limit to } 1 / 4 \text { of ration. Supplement with energy, } \\
\text { minerals, and vitamin A. }\end{array}$ \\
\hline Over 1.5 & Over 15,000 & TOXIC & $\begin{array}{l}\text { Forage should not be fed. If forage must be fed, } \\
\text { limit to less than } 15 \% \text { of ration. }\end{array}$ \\
\hline
\end{tabular}

Adapted from Southern Forages $4^{\text {th }}$ Edition, 2007.

As nitrogen fertilization is increased to stimulate yield, the chance of nitrate accumulation in commonly used forages also increases, especially when growth is limited by moisture stress (Crawford et al., 1966; Emerick, 1974; Hanway and Englehorn, 1958; May et al., 1990; Murphy and Smith, 1967; Wright and Davison, 1964). Observations and limited research have associated 
manure application in nitrate accumulation in both cool and warm-season annual grasses (Olson and Kurtz, 1982; Hanway and Englehorn, 1958; Mayo, 1895; Wright and Davison, 1964). Hanway and Englehorn (1958) found that significant amounts of nitrate accumulated in corn stalks that had been fertilized with manure. However, the nitrogen content of the manure was not documented making it difficult to draw any firm conclusions as to the effect of nitrogen source and rate on the accumulation of nitrate in forages.

Hay and pastureland is a common post-mining land use (Ditch and Collins, 2000) and forages are commonly planted on mined land that has been amended with high rates of biosolids (Haering et al., 2000). The accumulation of dangerous or toxic levels of nitrate in plant tissue that will be used for livestock feeding is a serious concern that has received little attention. The objective of this research study was to document the effect of soil reconstruction methods on the concentrations of nitrate in forage tissue.

\section{Methods}

The experimental design was a complete block design with a strip-plot treatment arrangement (Gomez and Gomez, 1984) and four replications. Vertical strips consisted of three soil reconstruction treatments and horizontal strips consisted of two nitrogen $(\mathrm{N})$ rates. Plot size was 15 x $84 \mathrm{~m}$. Soil reconstruction treatments were:

1) Control: ripping, $9 \mathrm{Mg}$ lime and $674 \mathrm{~kg} \mathrm{P}_{2} \mathrm{O}_{5}$ per ha, and N-P-K fertilization per crop management protocols;

2) Biosolids: ripping, lime-stabilized biosolids at $78 \mathrm{Mg}$ per ha and $\mathrm{N}-\mathrm{P}-\mathrm{K}$ fertilization per crop management protocols;

3) Topsoil: ripping, $9 \mathrm{Mg}$ lime and $674 \mathrm{~kg} \mathrm{P}_{2} \mathrm{O}_{5}$ per ha applied prior to topsoil return, $15 \mathrm{~cm}$ of topsoil return from a near by wooded area, and N-P-K fertilization per crop management protocols.

Prior to soil reconstruction, all plots were deep ripped in two perpendicular directions with a multi-shank (3) ripper attachment mounted on a Caterpillar D-8 bulldozer to $90 \mathrm{~cm}$, and one subsequent pass with a chisel plow (15 to $20-\mathrm{cm}$ ) was made over all the plots. The $\mathrm{N}$ treatments were no nitrogen and $252 \mathrm{~kg} \mathrm{~N}$ per ha $(84 \mathrm{~kg}$ per ha in March, $84 \mathrm{~kg}$ per ha after the first cutting 
and $84 \mathrm{~kg}$ per ha in late August). These treatments were imposed in the spring of 2006 after the first cutting was completed.

Nitrogen, P, K, and lime were applied in the fall of 2005 according to soil test recommendations and plots were seeded in early October. The seeding mixture consisted of $56 \mathrm{~kg}$ per ha of 'Jesup' tall fescue [Schedonorus phoenix (Scop.) Holub] infected with the MaxQ endophyte (Pennington Seed Company, Madison, GA), $28 \mathrm{~kg}$ per ha of 'WP-300' orchardgrass (Dactylis glomerata L.) (Evergreen Seed Company, Rice, VA), $11 \mathrm{~kg}$ per acre of 'Tryant' red clover (Trifolium pratense L.) (Evergreen Seed Company, Rice, VA) and 'Magnagraze' alfalfa (Medicago sativa L.) (Dairyland Seed Company, WI), and $4 \mathrm{~kg}$ per ha of 'Pinnacle' ladino clover (Trifolium repens L.) (Evergreen Seed Company, Rice, VA). In January 2006 two plots (topsoil and control) on the south side of the experimental area were destroyed when an adjacent area was remined. The control was relocated to the north side of the third replication. The topsoil treatment from the second replication is considered a missing plot.

Plots were harvested twice in the year following establishment (22 May 2006 and 07 Aug 2006) and once in 2007 (23 May 2007). Yield was determined by clipping a 1.2 x $31 \mathrm{~m}$ strip through the center of each plot using a self-propelled sickle-bar type forage harvester (Swift Machine Company, Swift Current, SK). A subsample of fresh forage was collected for nitrate analysis from each plot and dried in a forced air oven for $5 \mathrm{~d}$ at $60^{\circ} \mathrm{C}$. The forage was then ground to pass through a $2 \mathrm{~mm}$ and $1 \mathrm{~mm}$ screen using Wiley (Thomas Scientific, Swedesboro, NJ) and Cyclone sample mills (Udy Corporation, Fort Collins, Co), respectively.

Nitrate concentrations in plant tissue were determined colorimetrically using a modified salicylic acid method (Cataldo et al., 1975). Nitrates were extracted by placing $1 \mathrm{~g}$ of dried forage material in a $250 \mathrm{ml}$ Erlenmeyer flask along with $100 \mathrm{ml}$ of distilled water. This mixture was shaken for $1 \mathrm{hr}$ and then filtered through Whatman \#4 filter paper. A $200 \mu \mathrm{l}$ aliquot of sample extracts and nitrate standards $(0,10,20,30,40,60,80$, and 100 ppm nitrate-N) were pipetted into $30 \mathrm{ml}$ glass bottles along with $800 \mu \mathrm{l}$ of salicylate/sulfuric acid reagent and swirled. Sample blanks were prepared by pipetting a second $200 \mu \mathrm{l}$ aliquot of sample extracts into $30 \mathrm{ml}$ glass bottles along with $800 \mu \mathrm{l}$ of reagent grade $\mathrm{H}_{2} \mathrm{SO}_{4}$. After 20 minutes, $19 \mathrm{ml}$ of $2 \mathrm{~N} \mathrm{NaOH}$ was pipetted into each bottle. After 60 minutes of cooling, the absorbencies of the standards, samples, and sample blanks were read on a spectrophotometer set to $410 \mathrm{~nm}$ and zeroed using a 
blank (distilled water + salicylate/ $\mathrm{H}_{2} \mathrm{SO}_{4}$ reagent $+\mathrm{NaOH}$ ). A regression equation was determined for the standards and this equation was used to calculate nitrate- $\mathrm{N}$ concentrations in the extracts after the absorbance of the corresponding sample blank was subtracted out. This value was multiplied by 4.43 and reported as ppm nitrate-ion.

Data were analyzed using the general linear model procedure from SAS version 9.1 (SAS Institute Inc., Cary, NC). Main effects and interactions included in the model were soil reconstruction, $\mathrm{N}$ rate, and soil reconstruction $\mathrm{x} \mathrm{N}$ rate. Means were separated using Fisher's protected least significant difference $(\mathrm{P} \leq 0.05)$.

\section{$\underline{\text { Results and Discussion }}$}

Proper seed placement and timely rainfall in the fall of 2005 resulted in excellent forage stands. In 2006, annual rainfall was above normal, but the distribution was skewed toward summer and fall (Fig. 1). Rainfall early in the 2006 growing season (March to May) was only $44 \%$ of normal. In 2007, total annual rainfall was more than $100 \mathrm{~mm}$ below normal. For the period from June to November rainfall was $24 \%$ below normal.

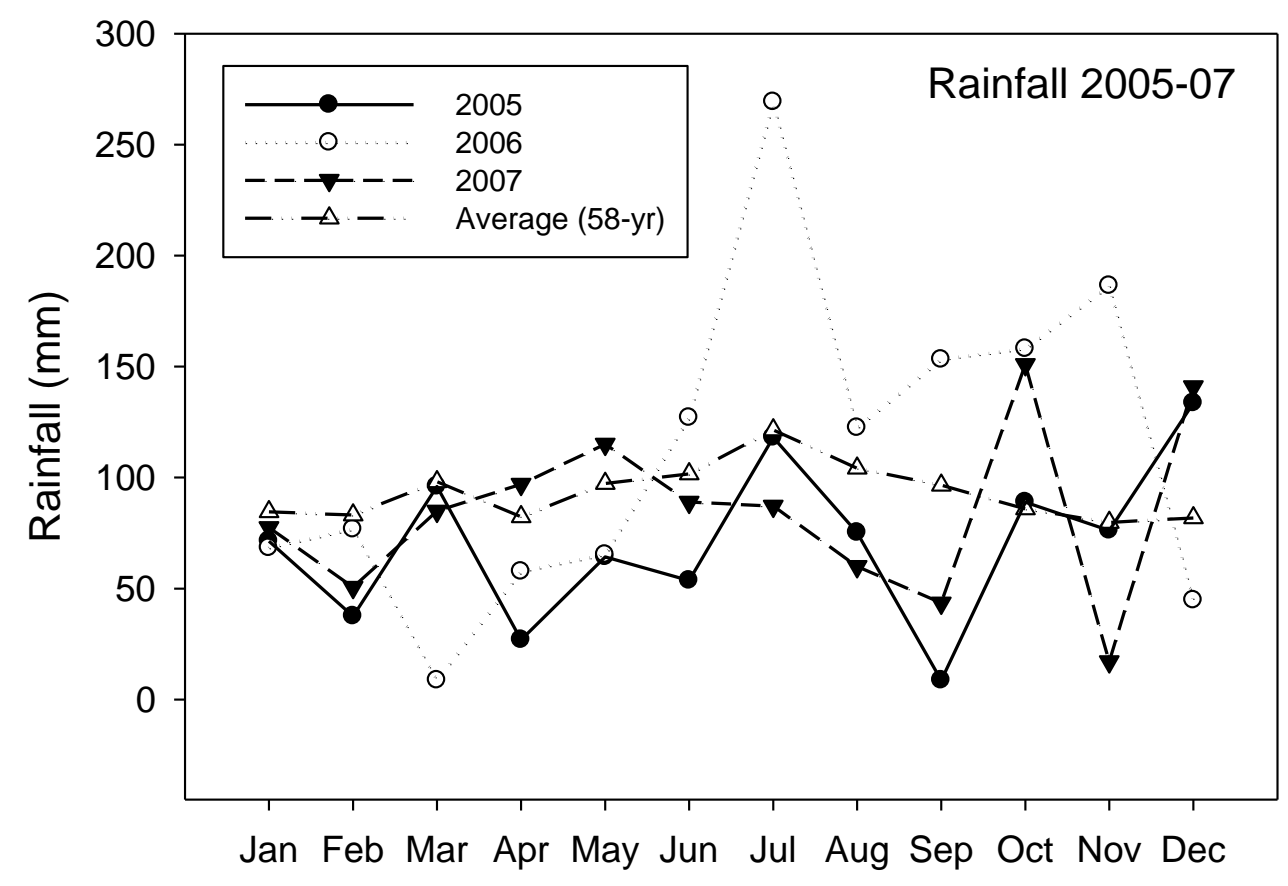

Figure 1. Rainfall data for the 2005, 2006, and 2007 growing seasons. Data was collected at the Southern Piedmont AREC, Blackstone, VA. 
Nitrate Concentrations in the Forage Tissue

No $\mathrm{N}$ fertilization $\mathrm{x}$ soil reconstruction method interactions were found for the 2006 and 2007 growing seasons. Therefore, the main effects of $\mathrm{N}$ fertilization and soil reconstruction method are presented. Yield, nutritive value, and botanical composition data are available in an accompanying article in these proceedings.

The level of biosolids used in this experiment (78 dry $\mathrm{Mg}$ per ha) resulted in the accumulation of high levels of nitrate in the forage tissue the year after establishment (2006). First harvest forage tissue from the biosolids treatment contained dangerous levels of nitrate (Fig. 2) and should be fed only in a total mixed ration not to exceed one-fourth of the total ration (Table 1). The forage from this treatment could be safely fed to horses as long as nitrate levels do not exceed 1.5\% (J.B. Meldrum, personal communication, 2005). In contrast, first harvest forage tissues from the control and topsoil treatments were in the safe range (Fig 2).

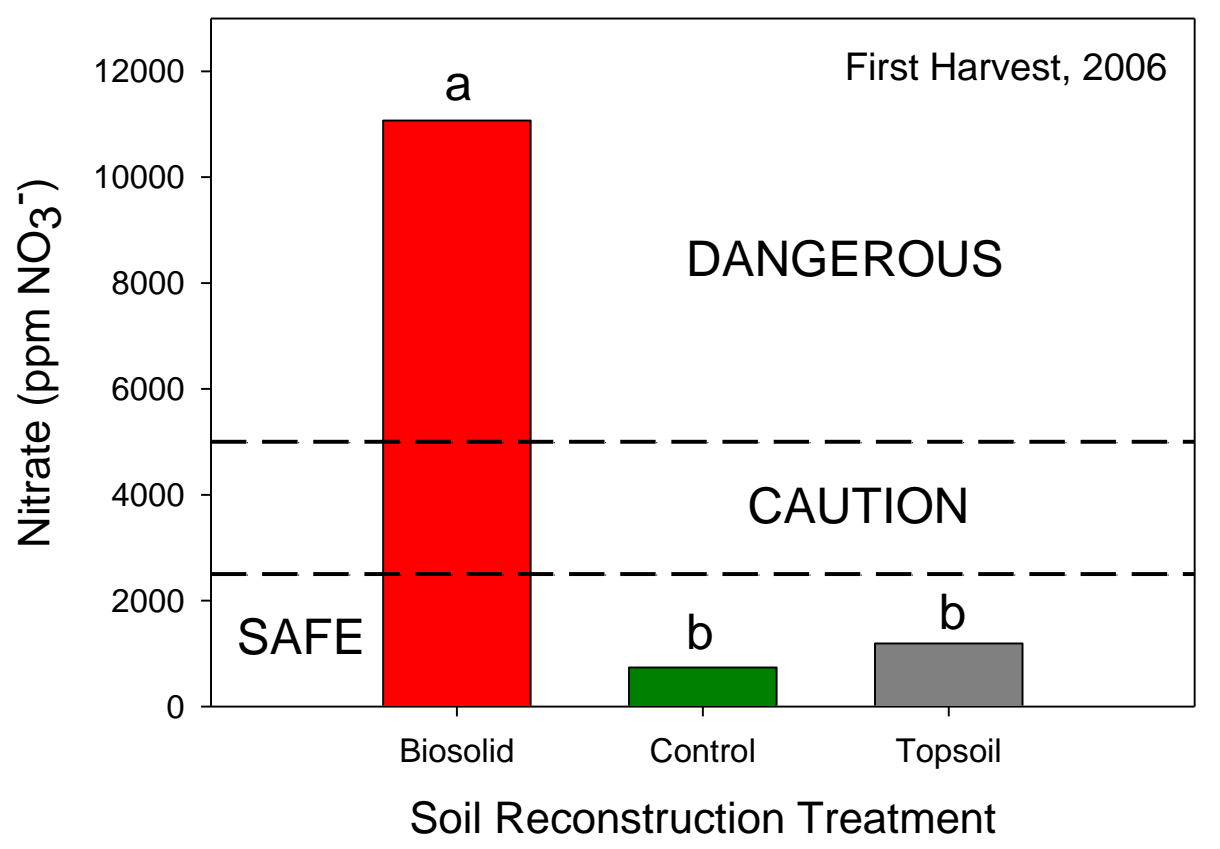

Figure 2. Nitrate concentration in the forage tissue as impacted by soil reconstruction treatment for the first harvest in 2006. Bars with the same letter are not significantly different according to Fisher's protected least significant difference $(\mathrm{P}=0.05)$. 
By the second harvest in 2006, nitrate concentrations in the forage tissue from the biosolids amended plots had increased to the toxic range (Fig. 3). This forage should not be fed to ruminant livestock or equine (Table 1). The higher nitrate concentrations for this treatment may have been related to temperature. As temperature increases the organic-N mineralization rate tends to increase (Stanford, 1982). Further cool-season forage growth tends to be slower at elevated temperatures (Moser and Hoveland, 1996). The combination of increased plant available N (PAN) and slowed plant growth may have created ideal conditions for nitrate accumulation in the biosolid treatment. Note that the control and topsoil treatment never accumulated significant quantities of nitrate (Fig. 3).

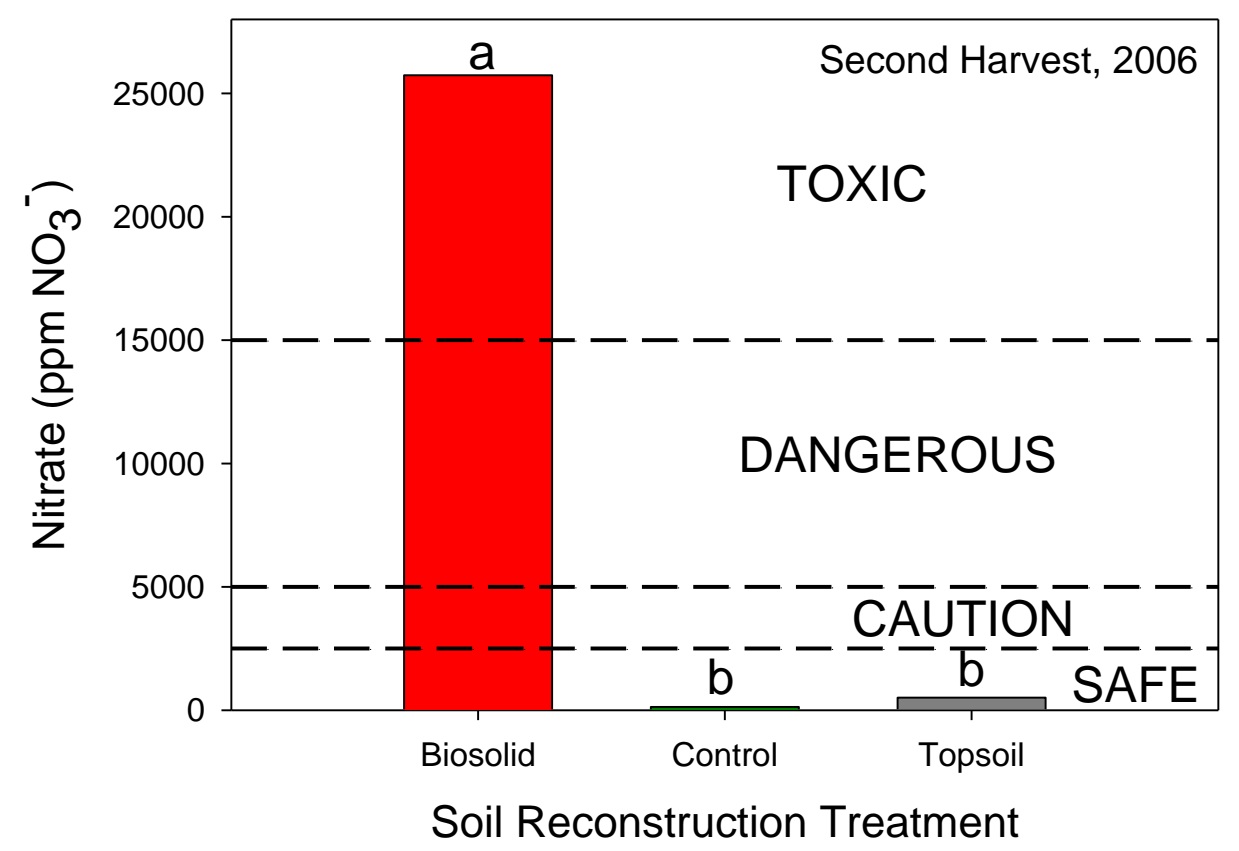

Figure 3. Nitrate concentration in the forage tissue as impacted by soil reconstruction treatment for the second harvest in 2006. Bars with the same letter are not significantly different according to Fisher's protected least significant difference $(\mathrm{P}=0.05)$.

Nitrate concentrations for the first and only harvest in 2007 were higher for the biosolid treatment, but all soil reconstruction treatments were in the safe range (Fig. 4). By the second year after establishment the rate of mineralization for the biosolids had likely decreased resulting in lower levels of PAN. Second year nitrogen availability from biosolids is estimated to be $10 \%$ of the total N (VDCR, 2005). 


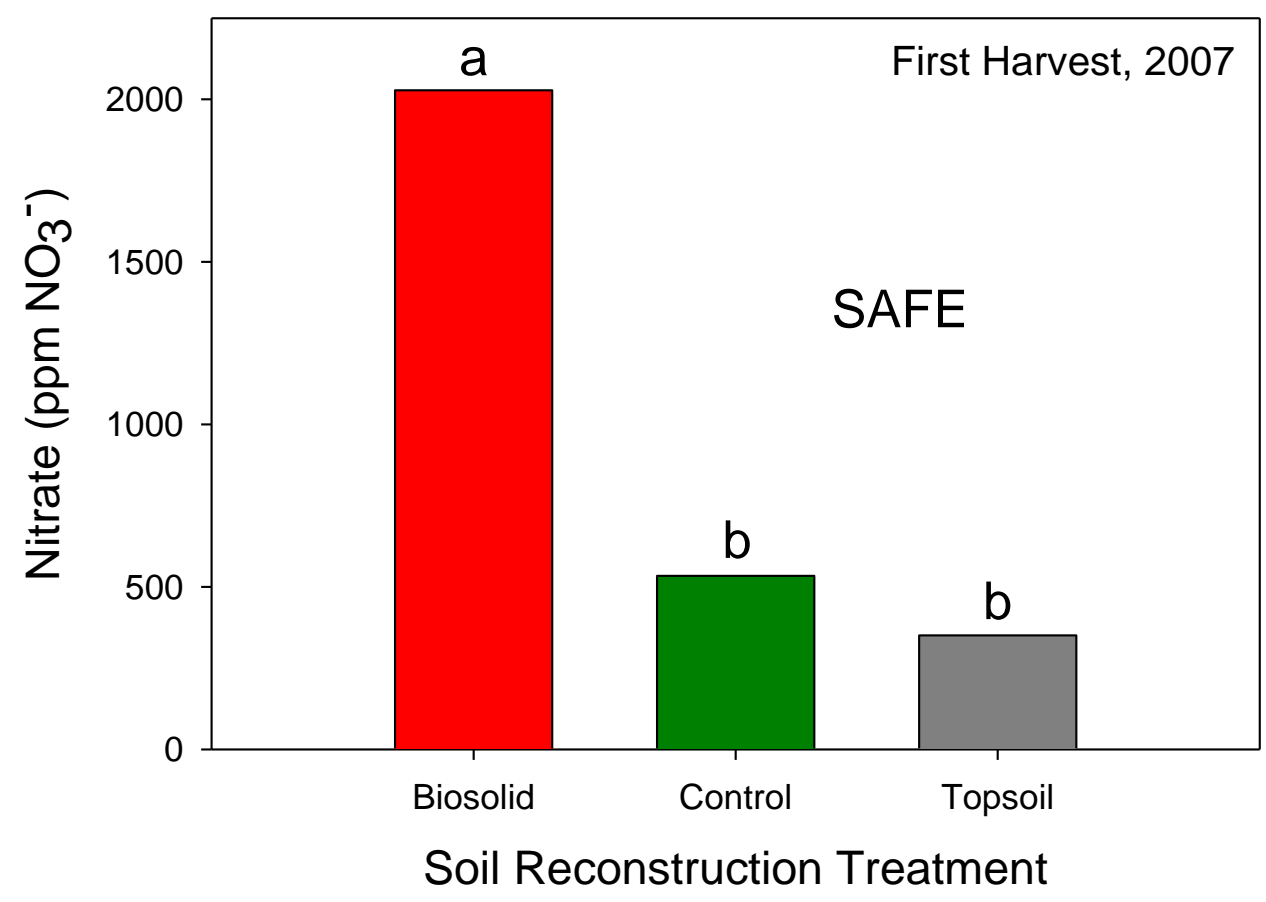

Figure 4. Nitrate concentration in the forage tissue as impacted by soil reconstruction treatment for the first harvest in 2007. Bars with the same letter are not significantly different according to Fisher's protected least significant difference $(P=0.05)$.

In 2006, the addition of nitrogen fertilizer did not increase the concentration of nitrate in the forage tissue for the first or second harvests (Fig. 5). Nitrogen fertilization did increase nitrates in the forage tissue in 2007 (Fig. 5). However, the levels of nitrate present in the forage tissue at this harvest posed no risk to ruminant livestock or equine (Table 1).

\section{Conclusions and Recommendations}

These data indicate that when high levels of biosolids are used in reclamation programs, forages will likely accumulate dangerous levels of nitrate. Therefore, when forage is being utilized as livestock feed, it should be monitored for nitrates for at least two complete seasons following the year of application. Since nitrate accumulation in forages can be impacted by environmental conditions, it is especially important to monitor nitrates if drought occurs during this period. 


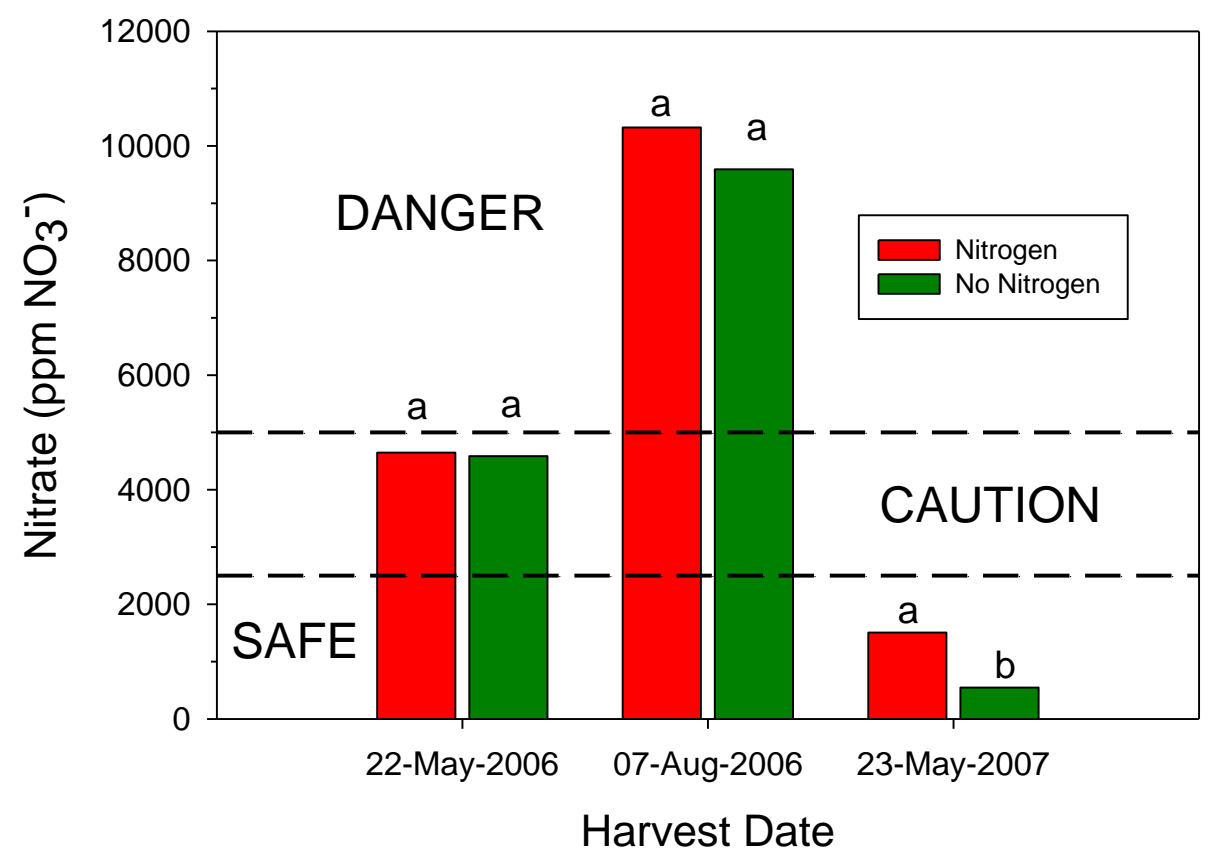

Figure 5. Nitrate concentration in the forage tissue as impacted by $\mathrm{N}$ fertilization for the first and second harvest in 2006, and the first and only harvest in 2007. Bars within a harvest date with the same letter are not significantly different according to Fisher's protected least significant difference $(\mathrm{P}=0.05)$.

\section{Acknowledgements}

The authors would like to acknowledge Iluka Resources, Inc. for their financial support of this research and the Winn-Caraway family for allowing us to conduct this research on their family farm.

\section{$\underline{\text { Literature Cited }}$}

Baker, J. M. and B. B. Tucker. 1971. Effects of rates of N and P on the accumulation of NO3-N in wheat, oats, rye and barley on different sampling dates. Agron. J. 63:204-207. http://dx.doi.org/10.2134/agronj1971.00021962006300020002x.

Ball, D. M., C. S. Hoveland, and G. D. Lacefield. 2007. Southern forages 4th edition. Potash and Phosphate Institute and Foundation for Agronomic Research, Norcross, GA.

Cataldo, D. A., M. Haroon, L. E. Schrader, and V. L Youngs. 1975. Rapid colorimetric determination of nitrate in plant tissue by nitrification of salicylic acid. Commun. Soil Science and Plant Analysis 6(1):71-80. http://dx.doi.org/10.1080/00103627509366547. 
Cheeke, P. R. 1998. Natural toxicants in feeds, forages, and poisonous plants, 2nd edition. Interstate Publishers, Inc., Danville, IL.

Crawford, R. E., W. K. Kennedy, and K. L. Davison. 1966. Factors influencing the toxicity of forages that contain nitrate when fed to cattle. Cornell Vet. 57:3-17.

Ditsch, D. C. and M. Collins. 2000. Reclamation considerations for pasture and hay lands receiving sixty-six or more centimeters of precipitation annually. p. 241-272. In R. I. Barnhisel, R. G. Darmody, and W. L. Daniels (eds.) Reclamation of drastically disturbed lands. ASA, CSSA, and SSSA, Madison, WI.

Emerick, R. J. 1974. Consequences of high nitrate levels in feed and water supplies. Fed. Proc. 33:1183-1187.

Gilbert, C. S., H. F. Eppson, W. B. Bradkey, and O. A. Breath. 1971. Nitrate accumulation in cultivated plants and weeds. Bulletin No. 227. University of Wyoming Agricultural Experiment Station, Laramie.

Gomez, K. A. and A. A. Gomez. 1984. Statistical procedures for agricultural research, second edition. John Wiley and Sons, NY.

Haering, K. C., W. L. Daniels, and S. E. Feagley. 2000. Reclaiming mined lands with biosolids, manures, and papermill sludges. p. 615-644. In R .I. Barnhisel et al. (eds.) Reclamation of Drastically Disturbed Lands. Agron. Mongr. 41. ASA, CSSA, and SSSA, Madison, WI.

Hanway, J. J. and A. J. Englehorn. 1958. Nitrate accumulation in some Iowa crop plants. Agron. J. 50:331-334. http://dx.doi.org/10.2134/agronj1958.00021962005000060013x.

May, M. L., J. M. Phillips, and G. L. Cloud. 1990. Drought induced accumulation of nitrate in grain sorghum. J. Prod. Agric. 3:238-241. http://dx.doi.org/10.2134/jpa1990.0238.

Mayo, N. S. 1895. Cattle poisoning by nitrate of potash. Kansas Agr. Exp. Sta. Bul. 49.

Moser, L. E. and C. S. Hoveland. 1996. Cool-season grass overview. p. 1-14. In L.E. Moser et al. (eds.) Cool-Season Forage Grasses. Agron. Mongr. 34. ASA, CSSA, and SSSA, Madison, WI. http://dx.doi.org/10.2134/agronmonogr34.c1 
Murphy, L. S. and G. E. Smith. 1967. Nitrate accumulation in forage crops. Agron. J. 59:171174. http://dx.doi.org/10.2134/agronj1967.00021962005900020015x

Olsen, R. A. and L. T. Kurtz. 1982. Crop nitrogen requirements, utilization and fertilization. p. 567-604. In F. J. Stevenson (ed.) Nitrogen in Agricultural Soils. Agron. Mongr. 22. ASA, CSSA, and SSSA, Madison, WI.

Page, A. L and A. C. Chang. 1994. Overview of the past 25 years: technical perspective. p. 3-6. In C. E. Clapp et al. (eds.) Sewage Sludge: Land Utilization and the Environment. SSSA Misc. Pub. ASA, CSSA, and SSSA, Madison, WI.

Stanford, G. 1982. Assessment of soil nitrogen availability. p. 651-88. In F. J. Stevenson (ed.) Nitrogen in Agricultural Soils. Agron. Mongr. 22. ASA, CSSA, and SSSA, Madison, WI.

Virginia Department of Conservation and Recreation. 2005. Nutrient management standards and criteria. Available online at

http://www.dcr.virginia.gov/documents/StandardsandCriteria.pdf (verified 25 Feb 2008).

Wright, M. J. and K. L. Davison. 1964. Nitrate accumulation in crops and nitrate poisoning in animals. Adv. Agron. 14:197-217. http://dx.doi.org/10.1016/S0065-2113(08)60025-5. 